\title{
The Protection of Competition between National Law and EU Law: The Main Features in Public Contracts
}

\author{
Ida D'Ambrosio \\ Additional information is available at the end of the chapter \\ http://dx.doi.org/10.5772/intechopen.76411
}

\begin{abstract}
This article provides a general analysis of competition law and then focuses on competition-related issues within public contracts. First and foremost, the article tries to highlight the economic grounds that led to the introduction of laws to protect competition, as a functional tool for production efficiency. After a critical analysis of national and EU regulations on competition, the article analyses the relation between competition and public contracts, by making a distinction between a "micro" and a "macro" view of competition. The article aims at highlighting the main features of the code of public contracts, focusing also on the relation between two different principles: the protection of EU competition, on the one side, and the power of member states to determine their internal organisation, on the other side. The article also aims at understanding to what extent can the European Union protect free competition without affecting the organisational freedom of its member states.
\end{abstract}

Keywords: competition, antitrust, competition law, public contracts, antitrust legislation

\section{Introduction}

In a wide sense, competition indicates a market situation with wide freedom of access to entrepreneurial businesses, with the possibility of free choice for buyers (in particular, consumers) and, in general, the possibility for each to exploit the best opportunities available on the market, or to propose new opportunities, without impositions on the part of the state or restrictions imposed by coalitions of enterprises. Competition is protected by a series of provisions, generically defined as antitrust provisions, which discipline relations between entrepreneurs and which allow the regular execution of competitive relationships. 
In economy, competition is the condition in which several companies compete on the same market, understood as the ideal meeting place between demand and offer, producing the same goods or services (offer) which satisfy a number of buyers (demand). In competition no operator can influence the trend of negotiations by his own decisions.

To be able to speak of competition, it is necessary to verify the following requisites [1]:

- Large numbers of operators, both sellers and buyers.

- Freedom of entry or absence of barriers. If this requisite is not met, one must speak of imperfect competition.

- Product similarity. If this requisite is not met, one must speak of monopolistic competition.

- Perfect market information and transparency.

- Simultaneity of contracting, subsequent to a negotiating phase which allows all operators to obtain the necessary information.

There are different types, or degrees, of competition. One particular form is perfect competition: this refers to an ideal market condition in which the competition between the enterprises leads to a decrease in the purchase price which is equivalent to the marginal cost.

In perfect competition, every operator considers the price as a datum that cannot be modified. The market reaches a position of equilibrium when the transactions take place at the price that makes the quantity demanded and that offered equal, i.e. the equilibrium price [2]. The features of the equilibrium price are:

- Singleness: all the units of the product are sold at the same price.

- Existence: the equilibrium price must also be significant from the economic viewpoint; if the price did not cover the costs and allow for significant revenues, the merchandise would not even be produced.

- Stability: if spontaneously reached by negotiations, the price is stable; otherwise, the price is unstable, when the producers do not succeed in swiftly adjusting the offer, so that the price is destined to swing up and down forever.

Perfect competition is deemed as reached in an economic system if the demand and the offer are particularly elastic, so that the price of a product or service tends to be close to the marginal cost.

However, it has been the topic of in-depth debate, and today it is considered purely utopian, whereas an imperfect competition seems concretely achievable (so-called reasonable competition), in which the price decreases towards the marginal cost but without reaching it.

The concept of competition was developed by the critics of mercantilism as of the second half of the eighteenth century, as a natural result of the fundamental freedom of the individual, in contrast to a state-controlled economy in which the state determines what and how much is produced. 
Various advocates of classic economy maintained that the market could autonomously regulate itself [3].

Others stated that competition can alone regulate the mechanisms of the economy and, furthermore, that the individual, pursuing his individual interest, also benefited the society as a whole [4].

According to the economists of the neoclassical school, the main advantages for the economy resulting from competition can be summed up in two main aims: the maximum increase of the quality/ price ratio of the goods and services (through the optimisation of the production factors) and the elimination (through competition) of the competitors that are unable to achieve the first aim.

Always, according to the neoclassic theory, competition eliminates profit that has not been earned, thus ensuring an important factor of social justice.

The above-illustrated theories were the subject of strong criticism and denial already towards the end of the eighteen century, when it was shown that the theory of pure competition would be valid only in static situations and therefore could not be applied in practice in the analysis of real economies, which are dynamic by definition [5].

The Marxian interpretation of competition is radically different. According to this theory, perfect competition regards only the relationship of force between capitalists and does not eliminate the exploitation of the workers [6].

\section{The community antitrust legislation}

The term antitrust identifies that complex of legal provisions that regulate and favour free competition in the market. Antitrust legislation therefore has the purpose of preventing companies from adopting strategies that allow them to assume anticompetitive positions or to stipulate collusive agreements to the prejudice of the consumer. However, these same provisions are also a policy tool and, therefore, subject to the opinions and choices of policy in general. Antitrust is an institution with deep roots in history and in society [7].

The purpose of antitrust legislation is to sustain a free market economy, where every enterprise takes its own decisions independently of its competitors, in order to guarantee strong competition which leads to a more efficient distribution of goods and services, lower prices of the same and their higher quality and maximum innovation. Competition therefore plays a role of primary importance since it encourages the various operators on the market to obtain the maximum result possible and to then select those that are most efficient.

The main modern legislations are the result of the affirmation of economic liberalism which has produced two effects: on the one hand, the suppression of state-imposed restrictions on the economy, and on the other hand, the ban on enterprises to abuse dominant positions to the prejudice of competitors and consumers.

The first modern antitrust law was the Sherman Act, passed in the United States in 1890, for the purpose of prohibiting cartel conduct and attempts to monopolise the market [8]. In 1914 the 
Clayton Act [9] was added to that first body of rules, to regulate the phenomena of corporate concentrations, followed by the Federal Trade Commission Act which punishes conduct that is generically defined as "unfair" and which is applied in parallel to the Sherman Act. The difference between the Sherman Act and the Federal Trade Commission Act is of nature and of purpose: the criminal nature of the antitrust bans enshrined in the former, and the consequent punitive nature of the antitrust control carried out in application of these rules, compared to a form of administrative control over behaviour and antitrust action that favours the correctiverestorative aspect.

This American experience paved the way for Europe to create provisions to protect market competition, although the first provisions were adopted several decades later than in the United States, only after the end of the Second World War. Only then were the conditions ripe for the creation of the European Single Market, overcoming the political visions of the diverse countries based, above all, on interventionism and protectionism [10].

In Europe, a single system of antitrust control was adopted only in 1957, with the introduction into the Treaty of Rome of specific provisions to protect competition, focusing on the discipline of restrictive agreements, the abuse of dominating positions and state aid. In 1989, with a specific regulation [11], a specific set of rules was introduced for the antitrust control of concentration operations.

The noncompetition discipline is an essential element of European integration inasmuch as it must allow companies to compete at par conditions on the markets of all the member states, ensure the competitiveness of their products and services at the global level and, at the same time, protect the European consumers in the best way. The provisions on competition are contained in Arts. 101 and 102 of the Treaty on the Functioning of the European Union [12], which regard national provisions on corporate activities.

The competition policy is divided into two main aspects: on the one side, it provides for controlling companies' behaviour regarding agreements and concentrations, and on the other side, it provides for limiting state aid to national producers. The implementation of the EU policy on competition is the responsibility of the European Commission, with control jurisdiction reserved to the European Court of Justice. The member states are obliged to harmonise national legislation to the EU legislation.

In 1957 most of the member states had a competition policy, but the methods and intensity of the control differed greatly from one country to another. The creation of a standardised economic area could not be limited to the coexistence of the various national practices, but the differences between national legislations were too deep to be replaced by a uniform community legislation. National and community competition policies had to coexist.

A general principle of community policy on this issue is the ban on agreements between companies that have the purpose or the effect of preventing, limiting or distorting competition within the common market and can prejudice trade between the member states. Agreements on the prices of goods produced and placed on the market, agreements on the regions and areas where the products will be sold or distributed and agreements on the quantities to be produced are expressly banned. 
The Treaty bans the abuse of dominant positions on the common market (or on a substantial portion of the same) on the part of one or more companies where this can be prejudicial to trade between the member states. It therefore only sanctions the exploitation of a dominant position after the fact and does not allow the institutions of the union to control the concentration process.

On the control of state aid, the Treaty states, without allowing for exceptions, that state aid which distorts competition is incompatible with a common market. Political realism has prevented the use against the countries of the rigid wording adopted against companies, admitting that aid can be considered compatible (always providing that it does not alter the conditions of trade in a manner contrary to the common interest) if it is destined to facilitate the development of certain activities or certain economic regions, if it is to promote the execution of important projects of common European interest and, lastly, in the case of other categories of aid, if it is determined by a council decision.

To eliminate the distortions of competition, the Treaty regulates the selective measures of aid in favour of companies and specifies the general measures in favour of the economy that can turn out to cause distortion of competition. In the Treaty there is no distinction between private and public companies, and several community directives discipline the transparency of the public funds destined to the latter. The EU interventions aim to protect the competitive functioning of the market on the basis of a general principle of a liberalist type, while the determination of what is concretely admissible is based on extensive pragmatism.

\section{Protection of competition under Italian law}

Under Italian law an organic discipline on competition was adopted with considerable delay compared to the other industrialised companies: Germany, the United Kingdom and France adopted the first laws on this issue towards the end of the 1940s, whereas the rules on competition within the European Community, as mentioned above, were already contained in the Treaty of Paris in 1952 and the Treaty of Rome in 1957.

The reasons for this delay are due to the fact that Italy, for a long time, pursued an economic model based on the idea that the state had to play a fundamental role in the direction and protection of the corporate system, with an outlook towards national economic development, in which companies, on the one hand, accepted the limitations to the freedom of economic independence, in exchange for a system that protected the results acquired by the companies existing in the market.

This model is present in the Civil Code of 1942, and it was also confirmed in the Constitution of 1948 in Art. 41, which recognises and guarantees the right to economic initiative, ruling, in the first paragraph, that "Private economic initiative is free". The Constitutional Court, until 1990, seconded this view, refusing to pronounce judgements of a liberalist tendency, except in certain important exceptions such as the pharmaceutical industry and the telecommunications field.

With the promulgation of Law No. 287 of 10 October 1990, better known as the Antitrust Law, a radical change of direction was implemented, under the influence of the ideology of 
the free market, which dominates at the global level, and also according to the choices of the then European Community, more liberalist than initially. The Italian law swiftly approached the principles of free trade at the level of the legislation introduced. In this sense, the sudden introduction of the antitrust law occurred, but above all the principle of the protection of competition was introduced into the constitution in 2001 as well as the law to promote the competitive market in which parliament must approve every year.

However, if we consider the actual development of the legislation, we have to notice a much more uncertain process of development: the wealth of case law of the Constitutional Court has applied the principle of the protection of competition but restored the authority of the state instead of the regions, therefore, with purposes other than the original purposes of Art. 41.

The fact is that the principle of competition itself contains much ambiguity, because the model of market and of economy that is pursued would require many more clarifications and much more in-depth examination which both the letter of the law and the case law of the Constitutional Court are far from having achieved.

The real driving force that led Italy to adopt the provisions to protect competition was the creation of the European Single Market [13]. This gradually led to the introduction of new laws aimed at changing the role of the state, from manager to regulator. This change in state action represents what had already occurred at the European level, when the various countries tried to influence the market mechanisms, sometimes even substituting them and imposing the rules of the game. The regulator state, instead, according to what happened in the United States, played the super partes role of a severe regulator, supervisor and guarantor of trade relations. In both cases, the aim pursued was that of increasing the national economies, but in the first case, there were no great results inasmuch as the focus was more on the efficiency of the market rather than on operations to the advantage of competition.

Finally, with Law No. 287/1990 [14], Italian legislation also implemented the principles of community law, aimed at guaranteeing free competition which would allow for the creation of a European Single Market, avoiding possible abuse on the part of the operators. This definitively marked the change from a pro-intervention policy to a policy in favour of free competition. Thus, with this law, a constitutional value was protected, namely, the public interest/social usefulness contemplated by Art. 41 of the Constitution, which affirms the freedom of private economic initiative, consistent with the European context of which free competition, and the rules of its correct implementation perhaps represent the oldest and most solid pillar [15].

Right from its first article, Law No. 287/90 imposes the implementation of Art. 41 of the Constitution, thus affirming the right to a competitive market as a constitutionally protected right. A necessary consequence of this situation is the fact that public law now disciplines competition, for the first time in an objective sense, with a clear-cut reversal of the provisions of the civil code which, with regard to (unfair) competition, have the purpose of protecting the economic interests of the single entrepreneurs that may be harmed by competitors. The protection of competition (and of the market understood as a unicum) structured so that it imposes rules on the companies on the market of reference (geographic or substantial) has a determining influence on the behaviour and choices of those who buy the goods or services produced by the companies. 
The main aims of the antitrust law, in addition to that of guaranteeing companies the freedom to operate on the market, include that of protecting consumers, favouring an improvement in product quality and innovation without excessive price increases. A specification must be made regarding the concept of company, which with this law takes on a wider meaning than that which can be drawn from the civil code, since company means any entity that practises an economic activity, regardless of its legal status and its method of financing itself [16].

For the civil code, however, the company can be defined as an economic activity aimed at the production or the exchange of goods and services that the entrepreneur practises by means of a complex of assets organised according to that activity (company). In addition, Law No. $287 / 90$ also rules that public companies or prevalently state-owned companies must be subject to the aforesaid discipline, according to Article 8. The European Court of Justice has also expressed its opinion on this point, affirming that the antitrust law must be excluded only when the activity practised by a public power falls within its institutional duties, thus not representing a corporate business [17].

For that matter, the second paragraph states that companies that operate as monopolies on the market or which manage services of general economic interest are also excluded from the application of the law. With regard to the comparison between Italian law and community law, Italian law, on the basis of paragraph 1 of Art. 1, seems to impose two restrictions. The first restriction is that of the "single barrier", regarding the scope of application of national provisions which apply only if the fact does not fall within the scope of community law [18].

Therefore, national law is not applicable in the case of anticompetition effects that occur on the Italian market which are subject to community law because they involve the sphere of the single market. The second restriction regards the interpretation of the provisions, in which interpretation, as stated in paragraph 4 of Art. 1 of Law No. 287/90, "is based on the principles of the European Community law on competition" [19].

The Italian antitrust law has almost entirely adopted the European law. The cases of relevance for national law are those described in the European law on competition (except for state aid, disciplined only at the community level), and their rules substantially coincide, consequent to the precepts themselves which are mainly identical to the corresponding European provisions and to the special interpretative rule established by Art. 1, par. 4 of Law No. 287/1990, according to which national law must be interpreted and applied in conformity to the European laws in force.

The relevant cases are restrictive agreements, abuse of a dominant position and corporate concentrations.

The illegal agreements are agreements, agreed practices or decisions of associations of companies that have the purpose or the effect of preventing, limiting or falsifying competition on the national market. The unlawfulness of an agreement can be excluded when it fulfils all the conditions listed under Art. 4 of Law No. 287/1990. Unlawful agreements are to all effects null and void.

The ban on the abuse of a dominant position, however, aims to punish anticompetitive behaviour adopted by a company or companies with significant power on the market (abuse of an individual dominant position, in the first case, and abuse of a collective dominant position, 
in the second case). The behaviour aimed at obtaining supra-competitive profits or other benefits that cannot be obtained in a competitive situation (exploitation abuse) or at preventing the entry or the survival on the market of rival operators (impediment abuse) is abuse.

Concentrations of companies, however, are not in themselves banned, but they are subjected to a prior antitrust control procedure which can result in the companies being banned from carrying out the operation reported when it is found that this can create or reinforce a dominant position on the market.

The responsibility for supervising the application of the antimonopoly legislation in Italy is attributed to Independent Administrative Authority, the antitrust authority that guarantees competition and the market (Italian abbreviation: AGCM). The functions that the said authority performs and the powers that it exercises differ according to whether the operations in question are to form concentrations, to enter into agreements or to abuse a dominant position. In the first case, the authority subjects the reported operation to a prior control which can conclude in the full and unconditioned authorisation of the said operation, a conditioned authorisation subject to compliance with certain prescriptions imposed by the authority or a ban on the execution of the operation. In the second case, instead, the authority, finding an infringement of the antitrust rules, orders the company to cease the prejudicial behaviour, possibly also prescribing specific types of behaviour or structural measures necessary to restore the competitive functioning of the market, and, in the more serious cases, it issues administrative sanctions.

The antitrust authority must also ensure the local application of the European antitrust provisions. In this case, specific rules govern the coordination between the national authority and the commission.

The national authority's power is not exclusive, however, inasmuch as the courts also have power in the case of lawsuits for nullity, claims for compensation for damages and petitions for urgent court orders in the case of anticompetition agreements, in compliance with Arts. 101-102 TFUE [20]. The maintenance of this "double track" of jurisdiction is justified by the fact that the antitrust authority and the ordinary courts must protect different interests and therefore their work must be considered separate and autonomous. As has been stated, "the public enforcement entrusted to the antitrust authority pursues, in the interests of society as a whole, the protection of competition as a constitutionally protected form of market, whereas the need to protect the interests of private subjects prejudiced by the anticompetition behaviour of companies is achieved by the adoption of the provisions set out in Art. 33 of Law 287/90 by the ordinary courts" [21].

\section{The tools for the promotion and protection of competition in public contracts}

Competition has a direct impact on the law on public contracts and contributes to defining the field of application. This holds true for both the objective and the subjective spheres of the rules.

With regard to the first aspect, importance is taken on by the procedure of exemption from the application of the European provisions on public contracts relative to special sectors, aimed at ascertaining whether the activity "is directly exposed to competition on the freely accessible markets" [22]. 
The special sectors are those of electricity, gas, water, transport, ports and airports and the postal system, in which elements of natural monopoly are present (infrastructures that are, in antitrust jargon, essential facilities). For this reason they are not subject to European sector discipline, usually administered by independent authorities and regulations, aimed at creating the legal conditions to open the sector to competition [23].

The model is based on the idea that if one of the sectors is subjected to the same competitive pressure of nonregulated markets, this eliminates the risk of the operators' purchasing policy being distorted by noneconomic factors. Therefore, the special rules that oblige contractawarding bodies to respect the several times mentioned European principles of par condicio and of transparency and publicity become superfluous [24].

The exemption procedure is in the hands of the European Commission and involves an assessment between the market of the activity in question, of the geographic market of reference and of the full implementation and application of the sector legislation of the union. The criteria to assess the competition of the market are laid down by the provisions of the Treaty on the Functioning of the European Union, and they include "the features of the products or services in question, the existence of alternative products or services that can substitute the former on the demand or the offer side, the prices and the effective or potential existence of the products or services in question" [25].

An exemption request must be made by a single member state (but also, if allowed by national legislation, by the single contract-awarding body), and it must contain information on all the pertinent circumstances, including the state of implementation of the sector European legislation, in order to demonstrate that access to the market "is free in fact and in law" [26]. In the procedure, an assessment may be obtained from the independent supervisory authority.

To sum up, the market analysis tools typical of antitrust law influence, according to the results of the assessment which not by chance is in the hands of the European Commission appointed to apply the antitrust laws, the field of application of European law on public contracts. The sector of activity, to which an exemption provision is applied on the result of the abovedescribed procedure, always remains, as is also the case for the deregulated markets, subject to "the application of the legislation on competition" [27].

A similar important justification holds firm to also delimit the subjective profile of European law on public contracts, which is to say the European notion of a public law body, already present in the Public Contract Code and also in the packet of the European directives [28].

As it is known, the public law bodies are included among the "contract-awarding administrations", i.e. the public administrations in the strict sense (countries, territorial bodies, noneconomic bodies, etc.) to which the stricter publicity rules are applied because there is a greater risk of the purchasing policy being conditioned by noneconomic reasons [29].

The public law body is identified on the basis of three parameters: it must have legal personality, whether it is public or private; it must be subject to a dominating influence on the part of a public administration; and it must have been established to satisfy needs of general interests of a non-industrial and non-commercial nature, i.e. as a rule it produces public goods or public services according to a non-market logic. 
Above all, this last parameter has given rise to interpretative uncertainties and varying case law interpretations, sometimes more extensive and sometimes more restrictive [30].

As clarified by Directive 2014/24/EU, it must be maintained, on the basis of the case law of the European Court of Justice, that a subject is not a public law body if "it operates under normal market conditions, it aims to make a profit and it sustains the losses that may result from the practice of its business" [31]. If these elements exist, it is licit to suppose that the subject has been created to satisfy needs of general interest that are, in fact, of an industrial and commercial nature.

Also, in this case, it is essential to verify the factual and legal context in which the subject operates. The fact that the economic operator operates in a fully competitive context is a highly relevant element albeit not decisive in itself [32].

In fact, for the economic operator to be encouraged to make purchases aimed at selecting the competitor that offers the best conditions, it is first necessary to ascertain whether it is exposed to an effective competitive pressure, i.e. whether it is an operator "on the market". In addition it is necessary to assess whether the risk of losses deriving from bad management falls entirely on the company or if the losses are perhaps neutralised by lists and items charged to society as a whole. If this second condition is not met, the operator "on the market" cannot be considered "of the market", i.e. motivated by the same incentives as those of all the other operators.

In any case, the analysis of the market according to the techniques precisely of antitrust law is an essential tool to establish whether an economic operator can be qualified as a public law body and as such held to respect the rules imposed by European and national legislation on public contracts.

The contractual activity of a public administration, like a market operator, has many specialised features compared to the discipline normally applicable to agreements between private subjects. Some public contractual events can represent a danger for the need to protect competition and the equal competitive opportunities of the various private subjects interested in being contractual counterparties to a public administration.

There are two topics strictly connected to the administration's role on the market. The first topic regards the fact that acting publicly-inspired by logics of protecting the public interest-conditions the institutes and discipline of common law applicable to contracts between private subjects. The second topic regards the risk of possible alterations in the competitive balance of the market by mechanisms that allow for avoiding procedures of public evidence.

For the coexistence of the various interests that a public administration meets in its service to society as a whole, the fundamental concept of public interest must be redefined. The concept must include the principle of the protection of competition as well as all those guarantees for private subjects introduced by national and community law, which could seem an obstacle and a limitation to the effective pursuit of the specific purpose precisely of an administration that acts as a market operator. In fact, if the public interest is considered in terms of interest for the whole society, it is simpler and more correct to consider as functional to the overall 
efficiency of the administrative activity also the pro-competition laws underlying the selection of the public administration's economic counterparties and the introduction of rules that prevent the contract-awarding bodies from unilaterally avoiding the contractual restrictions and the responsibilities that bear on every market operator, by exploiting authoritative powers that take on the semblance of intolerable privileges if used to alter the balance of equal relations imposed by private law.

European and national law on public contracts [33] answers, among other things, the need to ensure transparency and equal conditions among the operators of the markets of reference. Both the bidders in tender procedures and the economic operators of the connected markets have the right [34] to pretend that the administration acts in a manner to ensure transparency and equal conditions and, therefore, the said operators are entitled to impugn the deeds of a call for tenders that does not respect that right [35].

The rules of public evidence thus take on a pro-competitive function. Consequently, the implementation provisions of these rules, when they do not achieve the said purposes, simultaneously breach the rules themselves and the principles of free competition.

From another aspect, it must be noted that a call for tenders and the following procedure delimit a specific market within the wider market of reference, and that in one case as in the other, the bordering markets up- and downstream are involved, in which free competition in relation to the purchase of goods and services instrumental to the performance, being goods and services inferred in the tender procedure, must also be safeguarded. Consequently, if the deeds that discipline the tender procedure (calls for tenders, specifications, regulations, etc.) require the bidders to equip themselves, for the contractual activity, with machines or apparatuses that have certain features for the purpose of admission to the bidding or to be awarded a higher score, the principle of the equality of the bidders is prejudiced and, at the same time, competitive parity among the companies that produce the goods with which they must equip themselves.

Consequently, the prejudiced companies will be entitled to request protection also from the administrative courts [36].

The said principle is also based on the freedom of economic activity sanctioned by Art. 41 of the Constitution and on the connected freedoms of establishment and of the circulation of goods and of services, legalised by the TFUE, which must be respected by the member states, which, as it is known, must "adopt every general or specific measure to ensure compliance with the obligations of the Treaty or consequent to deeds of the Union's institutions", while they must "abstain from any measure which risks prejudicing the achievement of the Union's objectives" [37].

The protection of competition must now be considered the main task of the countries [38].

As it is known, these freedoms depend on the principles and rules, both European and national, aimed at creating and maintaining a free and openly competitive market [39], which must be respected, also and above all, by the nations [40], which, therefore, must conform their action, including that concerning the purchase of goods and services supplied by private companies. 
It is now confirmed not only that the Public Contract Code also aims at reaching the objectives of protecting and promoting competition [41] but also at guaranteeing that competition represents the primary aim of the law on the awarding of public contracts [42]. Consequently, the contract-awarding body must also play a primary role in regulating and guaranteeing the market: the law on public contracts, over time and especially since the early 1990s, not only bans public administrations from abusing their dominant position, which, for obvious reasons, they occupy on the public contract market in general and in those "created" by the single-award procedures, in particular, but also requires that they exercise their functions and powers in a manner that ensures, first and foremost, competition "for the market" [43].

Article 101 and following of the TFUE in fact generate individual subjective legal situations worthy of protection against all legal subjects, which can be claimed not only for their nature of fundamental rights but also under Art. 33 of Law No. 287/1990, which entrusts to the Code of Administrative Procedure the discipline of legal protection in the case of the breach of the provisions of the said law, in parallel to civil lawsuit for nullity and for compensation pursuant to Art. 33, par. 2, cited above.

This is also confirmed by Art. 21-bis of Law No. 287/1990 which, in recognising the antitrust authority's right to sue, offers not only a case of extraordinary and exclusive legitimisation but also a power to act which, until now, was allowed only to private subjects prejudiced by a public authority's actions which breached the rules imposed to safeguard competition and the market [44]. The question of the nature of the interest that the antitrust authority holds can perhaps be solved starting from the consideration that said authority's right to sue, based on the public interest in repressing conduct which harms the principles which protect competition and the market, presumes that, normally, such a right is held by companies which suffer subjective prejudice due to the administration's anticompetition conduct, inasmuch as operating on markets influenced by the effects of such conduct.

The joint expenditure procedures, aimed at limiting corruption, are essential to guarantee the transparent, impartial and economic management of public funds, to the benefit of society as a whole and to the benefit of the quality and efficiency of the public administrations. The public evidence procedures represent the main tool to ensure the correct execution of free competition between the market operators that offer the public administrations labour, services and supplies.

The New Public Contract Code expressly contemplates, under Art. 30, that "The assignment and execution of contracts for works, labour, services, supplies and concessions guarantees the quality of the performance and respects the principles of economy, efficiency, timeliness and correctness. In awarding contracts and concessions, the awarding bodies must also respect the principles of free competition, non-discrimination, transparency, proportionality and of publicity. The awarding bodies cannot speciously limit competition in any manner in order to unduly favour or prejudice certain economic operators nor, in the procedure for awarding concessions, may they speciously influence the estimate of the value of certain works, supplies or services. The criteria for participating in tender procedures must not be such as to exclude the micro small and medium companies". 
The Public Contract Code also provides for many pro-competition institutions aimed at guaranteeing competition. These include the framework agreement, the electronic tender, the competitive procedure with negotiation, the competitive dialogue and the partnership for innovation.

Public administrations can influence the competitive functioning of the markets when they choose from among the various methods of assigning the service, work or supply and downstream of that choice, when preparing the call for tenders and/or the pre-information notices and the tender specifications, by reporting suspect cases and by collaborating with the contract-awarding bodies and the antitrust authority. The methods that the public administrations can use to efficiently satisfy their needs are the public evidence procedure or direct assignment, also known as in-house provision, within the strict limits established by community and national legal theory and case law.

The effects on competition of the organisation solution chosen by a public administration to efficiently satisfy its aims differ according to the "choice" adopted. In fact, in the case of the in-house provision of a service, competition is entirely excluded, whereas in the case of the assignment of the service to a company which is partly privately owned, the market rules, and therefore the tender procedure rules, must be respected.

The calls for tenders and the specifications must therefore be conceived in a manner such as to create the "pre-conditions" so that the comparison between the participating companies is based on criteria of non-discrimination, proportionality and transparency, as well as on the principle of the widest possible participation.

The New Code No. 50 of 2016, under Art. 51, expressly contemplates that the contract-awarding bodies, to favour access on the part of micro, small and medium enterprises, may divide the contract into lots according to function or performance. The value of the lots must be sufficient to guarantee the effective possibility of participation on the part of the micro, small and medium enterprises. In fact, the contract-awarding bodies are forbidden to break down the work into lots solely to avoid the application of the provisions of the Code or to award the contract by the specious aggregation of contracts. The awarding bodies must also explain why a contract is not divided into lots. In spite of this provision, the specious division of the contract into several lots on the part of an administration may occur. This mechanism may be to avoid the tender procedure obligations. According to the antitrust authority, for an effective comparison between the companies, the number of lots must be less than the number of bidders.

Above all, although the pro-competition purpose of temporary groupings of enterprises is well known, the antitrust authority has found that this tool Above all, although the pro-competition purpose of temporary groupings of enterprises is well known, the Antitrust Authority has found that this tool "must always be checked as to whether it is suitable in practice, since it can easily lead to a decrease in the degree of competition, if it allows subjects, which could participate independently, to make a joint bid with their own rivals, thus speciously decreasing the effective extension of the competition". Case law of the administrative courts has also pointed out the risks of a substantial distortion of the institute of the temporary association [45].

Also, in identifying one of the two criteria for the award, i.e. the lowest price and the economically most advantageous offer, it is necessary to guarantee (in addition to respect for the principles of transparency, non-discrimination and equal treatment) an assessment of the offers in a situation of effective competition. 


\section{Conclusions}

The law on public contracts has undergone a significant metamorphosis with the introduction of the principle and rules of free competition, sanctioned by the EC Treaty and by community law introduced into Italian law, most recently, with the Public Contract Code.

The "public evidence" procedures for the awarding of work, service and supply contracts no longer protect only the public, financial and administrative interests of the awarding bodies and do not only exclusively answer the principle of legality, but are aimed at guaranteeing the free circulation of goods and services on the domestic market and free competition at the European level.

The guarantee of a free market ensures the satisfaction of the public interest on both the financial and the administrative fronts, because effective competition limits prices and favours quality, since it can reward not only the less demanding contracting party but also the "fair" contracting party.

At the same time, the guarantee of a free market better satisfies the expectations and rights of the companies which, in the absence of effective competition, would risk suffering discrimination.

The logic of free competition at the European level requires the countries to have, as far as possible, the same laws to this regard. The said discipline in the Italian legal system is entrusted to the state in its capacity as legislator, to which the "protection of competition" is exclusively entrusted. This means that national law plays a very important role with regard to the essential legal features of public contracts.

Furthermore, the logic of competition brings with it an increase in the tools for guarantee available to the companies interested in the free market. This is the context of the Code, and in the light of this context, it must be interpreted and implemented.

In administrative law cases, public evidence procedures reinforce the remedies against discrimination, to the prejudice of the companies that are "new entries", exercised by the contract-awarding bodies. The Public Contract Code places additional obligations on the contract-awarding bodies in order to ensure authentic equality of treatment also in new negotiating procedures, such as competitive dialogue. The authority's role is consolidated in sector supervision, which monitors, among other things, the correctness of the competitive procedures by means of a wide range of powers. Therefore, free competition reinforces the principle of legality.

At the same time, the antitrust remedies in favour of companies excluded or prejudice by the illegal behaviour of competitors are reinforced: there are an increasing number of cases in which the antitrust authority punishes restrictive agreements entered into by competitors in the execution of public tender procedures for the awarding of contracts.

In short, the logic of competition and the European free market has a duel value in the case of tender contracts: it more effectively contrasts the excesses of the powers of both national and local public bodies which operate as contract-awarding bodies and of the powers of the entrepreneurs that continue to stand in opposition. 


\section{Author details}

Ida D’Ambrosio

Address all correspondence to: i.dambrosio@unifortunato.eu

Economic Law, Benevento, Italy

\section{References}

[1] Le Garzantine: Economia. Garzanti Editore. 2011. p. 316

[2] See [1]. Le Garzantine: Economia. Garzanti Editore. 2011. p. 316

[3] To this regard Adam Smith in The Wealth of Nations wrote: "Pure competition means remuneration for those who supply the best goods at the lowest price. It offers an immediate and natural reward that a crowd of rivals struggle to obtain, and it is more effective than a distant punishment that each one can hope to avoid"

[4] According to a maxim of Jeremy Bentham, "Generally no one knows your interests better than you know them yourselves, and no one is willing to pursue them with equal ardour and constancy"

[5] The most profound criticisms were developed above all by Joseph Schumpeter and John Maynard Keynes. They doubted that perfect competition could be achieved in practice, even sustaining, instead, that it was an infeasible and purely utopian ideal

[6] See [1]. Le Garzantine: Economia, Garzanti Editore. 2011. p. 316

[7] Silva F. Regole dell'efficienza e politica Antitrust. LIUC Papers No. 48 Series. Economica e Impresa. 1997. p. 2

[8] It is the oldest antitrust law of the United States, and it represents the first action of the US government to limit the monopolies and the cartels

[9] The Clayton Act introduced a greater control of concentration operations, introducing a ban on mergers by the purchase of assets or shares. The discriminating element of the Clayton Act consists of the greater rigidity of the criterion of legality of the "rule of reason" compared to the criterion of the Sherman Act, which refers to an assessment of the probable effect of any agreement or practice deemed as being restrictive to competition

[10] In 1951 the important Treaty of Paris was signed, establishing the first community organisation, the European Coal and Steel Community (ECSC), with the aim of introducing the free circulation of coal and steel and of guaranteeing free access to the production sources. This agreement paved the way for the drafting, a few years later, in 1957, of the Treaty of Rome which established the European Economic Community (EEC). The important abolition of custom duties was expected to favour trade between the member 
states and the creation of the European Single Market based on free competition among enterprises. Then, the EURATOM was signed, also in Rome, which established the European Atomic Energy Community (EAEC), with the aim of creating a community energy policy. The provisions of the Treaty of Rome were implemented by Regulation No. 17 of 21 February 1962, successively revised and updated with EC Regulation No. $1 / 2003$. This latter attributed greater responsibilities and freedom for implementation to the member states and to the companies themselves, eliminating in particular the exclusive competence of the commission in the application of the exemptions. In this way the national authorities and courts can directly apply the antitrust legislation

[11] Regulation 4064/1989/EEC was then substituted by Regulation 139/2004/EEC

[12] Arts. 101 and 102 of the Treaty on the Functioning of the European Union correspond to Arts. 81-89 of the prior version of the Treaty

[13] The European Single Market is a simple idea but is extremely difficult to put into practice. It is based on four fundamental freedoms: the free movement of people and of goods, the free performance of services, the freedom of establishment and the free circulation of capital [...]. The European Single Market is a combination of two concepts, the absence of barriers and competition: the absence of barriers concerns the four freedoms of movement, and competition only on national markets serves little if they are isolated considering the market on a continental scale and just as the opposite also serves little, i.e. the lack of barriers if there were not also competitive conditions. See M. Monti, Mercato Unico Europeo, Regolamentazione e concorrenza, Atti del Convegno Internazionale..., Rome. 1995. p. 1

[14] Law No. 287, "Provisions for the protection of competition and of the market", after having been approved by the senate on 27 September 1990, was published in the Official Journal of the European Union on 13 October, entering immediately into force

[15] Giacomini G. La Legge 10.10 .90 No. 287 and the new Art. 21-bis introduced by Decree Law No.138/2011. 2013. Available form: http://www.contegiacomini.net

[16] Mellone C. Il procedimento amministrativo davanti all'Autorità garante della concorrenza e del mercato. 2001. Available from: http://www.diritto.it

[17] Rangone N. Principi comunitari e disciplina interna della concorrenza: l'abuso della posizione dominante in un'analisi per casi in Riv. it. dir. pubbl. com. Milan, 1995. pp. 1305 and foll

[18] Pappalardo A. Il sistema sino ad oggi: rapporti tra legge No.287/1990 e diritto comunitario;diretta applicazione degli articoli 81 e 82, Adeguare l'ordinamento italiano al regolamento (CE) No. 1/2003: quali scelte normative per la modernizzazione dell'antitrust - Deeds of the Assonime Convention at the Supreme Court of Cassation. 2003

[19] See Art.1, paragraph 4, Law No. 287/90

[20] Mangini V, Olivieri G. Diritto antitrust. Giappichelli, Turin. 2012. p. 136

[21] Auteri P, Floridia G, Mangini V, Olivieri G, Ricolfi M, Spada P. Diritto industriale. Proprietà intellettuale e concorrenza, Giappichelli, Turin. 2012. p. 524 
[22] Art. 34 of Directive 25/2014/EU

[23] Articles 8-14 of the Directive of Annex III contain the list of the sector directives that the member. States are held to implement

[24] In the special sectors, unlike the ordinary sectors, the awarding bodies are often companies that do not use public resources to manage their activities. However, they are the holders of special and exclusive rights which give them a market power over the contractors, which must be mitigated by the publicly evident procedures at least as long as power is not neutralised by the existence of real competition also in implementation of the sector European directives aimed at liberalising the markets: see on this point S. Cadeddu-S. Fienga, Contratti pubblici di lavori, servizi e forniture nei settori speciali, in M. Clarich (edited by, op. cit., p. 1004 commenting on Art. 219 of the Code. See also A. Lalli, op. cit., p. 405 according to which the existence of an unacceptable level of competition in these sectors becomes "an autonomous and sufficient condition for the application of the legislation on tender contracts"

[25] In Art. 34, par. 2, with regard to the geographic market of reference, it is "the territory in which the companies concerned are involved in the offer and in the demand of products and services in which the competitive conditions are sufficiently similar" (par. 3)

[26] Par. 3, paragraph 2, of the cited directive

[27] Art. 34, par. 1 and recital 44

[28] Art. 2, par. 1 (No. 4) of Directive 2014/24/EU

[29] Art. 3, par. 25, of the Code. See G. Greco, Ente pubblico, impresa pubblica, organismo di diritto pubblico, in Riv. It. Dir. Pubbl. Com., 2000, pp. 839 and foll.; M.A. Sandulli, Organismi e imprese pubbliche, Milan, 2004; R. Caranta, Organismo di diritto pubblico e impresa pubblica, in Foro amm. - consiglio di Stato, 2005, pp. 1347 and foll. For the origin of notion which adopts the French distinction between établissements publics à caractère industriel e commercial and établissements publics à caractère administratif, M. Libertini, Organismo di diritto pubblico, rischio d'impresa e concorrenza: una relazione ancora incerta, in Contr. e Impr., 2008, pp. 1201 and foll. also for an in-depth examination of the ratio of the application of the law on public contracts

[30] With regard to the state of case law, see M. Libertini, Diritto della concorrenza, op. cit., pp. 548 and foll. also for the thesis according to which the restrictive notion is more preferable since only when an economic operator is not exposed to effective competition and/or the business risk do the above-mentioned agency problems that exist which justify the imposition of the public evidence procedures

[31] See recital No. 10

[32] See EC Court of Justice, 10 May 2001, cases C-223 and 260/99, Agorà vs. Excelsior, 42; 10 November 1998, case C360/96, BFI Holding BV, 48-49

[33] Thus, also the very recent Legislative Decree No. 50/2016. Art. 2 of Lgs. Decree No. $50 / 2016$ states, in fact, that the responsibility exercised by the state in implementing 
Directives 2014/23/EU, 2014/24/EU and 2014/25/EU must be, first and foremost, with regard to competition

[34] Art. 4 and 101 and foll. TFUE and Art. 41 and 117, par. 1, of the Constitution

[35] On the other hand, in the New Public Contract Code, as in the previous version, the interest (or, if you prefer, the value) of competition expressly comes up in many provisions (see, for example, Art. 23, parts 13, 30, 42, 54, 58, 63, 66, 67 and 68)

[36] This legitimate entitlement is punctually confirmed in Art. 68 of Lgs. Decree No. 50/2016, and specifically where in the wake of what is already contemplated by Art. 68 of Lgs. Decree No. 163/2006, it rules that "The technical specifications must allow equal access on the part of the economic operators to the award procedure and must not directly or indirectly involve unjustified obstacles to the opening of public contracts to competition" (par. 4). In addition to that, "Unless justified by the purpose of the contract, the technical specifications cannot mention a manufacturer or a determined provenance or a specific procedure featuring products or services supplied by a specific economic operator, nor may they refer to a trademark, a patent or a specific type, origin or production which would have the effect of favouring certain companies or certain products. Such mentions or references are allowed, however, in exceptional cases if a sufficiently precise and intelligible description of the purpose of the contract is not possible with the application of paragraph 5. In such a case the mention or reference must be accompanied by the expression "or equivalent". And, it must be added that the provision applies for all the more reason, when the reference, indication, etc. is not explicit but inferred or encrypted by a reference

[37] See Art. 4 TFUE and Art. 117, par. 1, of the Constitution

[38] Libertini M. Diritto della concorrenza dell'Unione Europea, Milan, 2014, pp. 511 and foll

[39] See Artt. 101 and foll. TFUE

[40] See, for example, Art. 106 TFUE

[41] See EC Court of Justice, 12 December 2002, C-470/99, Universale-Bau

[42] Sandulli MA. in Tratt. sui contratti pubblici dir. by M.A. Sandulli, R. De Nictolis, R. Garofoli, I, 2008, specc. 8 and foll; see also the Court of Auditors, legal div. Lombardy, 17.7.2006, No. 447, according to which "the main aim of the public evidence law of Community derivation is to favour competition". This assumption was precisely and unequivocally expressed in the judgement of the Constitutional Court No. 401/2007 (in Giur. cost., 2007, 4447 and foll., with notes by L. CAssetti AND C. Lombardi), which recognised the protection of competition as the underlying ratio of Lgs. Decree No. 163/2006

[43] See [42], M.A. Sandulli

[44] See Lazio TAR. (Regional Administrative Court), Rome, div. III, 15.3.2013, No. 2720

[45] Council of State, judgment 8 March 2006, No. 1267 